\title{
TINGKAT KERENTANAN PESISIR DI UTARA DAN TIMUR PULAU BINTAN PROVINSI KEPULAUAN RIAU TAHUN 2020
}

\section{THE COASTAL VULNERABILITY LEVEL IN THE NORTH AND EAST COAST OF BINTAN ISLAND RIAU ARCHIPELAGO PROVINCE ON 2020}

\author{
Mario Putra Suhana ${ }^{1}$, Risandi Dwirama Putra ${ }^{2}$, Leica Febby Shafitri ${ }^{1}$, Muhamad Muliadi ${ }^{1}$ Khairunnisa $^{1}$, \\ I Wayan Nurjaya ${ }^{3}$, Nyoman Metta N. Natih ${ }^{3}$ \\ ${ }^{1} J u r u s a n$ Ilmu Kelautan, Universitas Maritim Raja Ali Haji, Tanjungpinang \\ ${ }^{2}$ Jurusan Teknik Perkapalan, Universitas Maritim Raja Ali Haji, Tanjungpinang \\ ${ }^{3}$ Departemen Ilmu dan Teknologi Kelautan, Fakultas Perikanan dan Ilmu Kelautan, IPB University \\ Korespondensi: risandi@umrah.ac.id
}

\begin{abstract}
Coastal areas are unique, dynamic, and complex because they are zones of interaction between land, oceans, and atmosphere. This makes coastal areas the most vulnerable areas on Earth. To find out how big the vulnerability is in a coastal area, a study is needed to determine the vulnerability level of coastal areas and the influencing factors. Research on the coastal vulnerability level at this location was conducted in 2016 and it was concluded that the coastal vulnerability level is in the medium category. With the development of potential utilization in the area, it is necessary to conduct similar research in 2016 to find out if there is a change in vulnerability level between 2016 and 2020. The data used consisted of coastal geomorphology, tidal, Landsat 7 ETM+ and 8 OLI, sea level rise and DEM satellite imagery. Data analysis using Coastal Vulnerability Index (CVI) method. The results showed the coastal vulnerability level at the research site was in the low-medium category, with a CVI score range of 9,93-25,86. Topography, geomorphology, intensity of shoreline changes, and coastal slope are factors that can cause the vulnerability level at the research site can be very high. However, the interconnectedness between other parameters can inhibit the high level of vulnerability, making the level of coastal vulnerability at the research site to be only in the low-medium category. There was a change in vulnerability level conditions between 2016 and 2020 the level of vulnerability at the east coast decreased to a low category.
\end{abstract}

Keyword: Bintan Island, coastal vulnerability, CVI method

\begin{abstract}
ABSTRAK
Wilayah pesisir sangat unik, dinamis, dan kompleks karena merupakan zona interaksi antara daratan, lautan, dan atmosfer. Hal ini menjadikan wilayah pesisir sebagai wilayah yang paling rentan di Bumi. Untuk mengetahui seberapa besar kerentanan di suatu wilayah pesisir, perlu dilakukan penelitian untuk mengetahui tingkat kerentanan wilayah pesisir dan faktor yang mempengaruhi. Penelitian mengenai tingkat kerentanan pesisir di lokasi ini pernah dilakukan pada tahun 2016 dan diperoleh simpulan bahwa tingkat kerentanan pesisir berada pada kategori sedang. Dengan semakin berkembangnya pemanfaatan potensi di daerah tersebut maka dirasa perlu dilakukan penelitian serupa dengan tahun 2016 untuk mengetahui apakah terdapat perubahan tingkat kerentanan antara tahun 2016 dengan tahun 2020. Data-data yang digunakan terdiri dari Data-data yang digunakan terdiri dari geomorfologi pantai, pasang surut, citra satelit Landsat 7 ETM+ dan 8 OLI, kenaikan muka laut dan DEM. Analisis data menggunakan metode Coastal Vulnerability Index (CVI). Hasil penelitian menunjukkan tingkat kerentanan pesisir di lokasi penelitian berada pada kategori rendah-sedang, dengan kisaran skor CVI 9,93-25,86. Topografi, geomorfologi, intensitas perubahan garis pantai, dan kemiringan pantai merupakan faktor yang dapat menyebabkan tingkat kerentanan di lokasi penelitian menjadi sangat tinggi. Namun, keterhubungan antara parameter lain yang dapat menjadi faktor penghambat tingginya tingkat kerentanan, menyebabkan tingkat kerentanan pesisir di lokasi penelitian hanya berada dalam kategori rendahsedang. Terdapat perubahan kondisi tingkat kerentanan antara tahun 2016 dengan tahun 2020 dimana pada tahun 2020 tingkat kerentanan di pantai timur mengalami penurunan menjadi kategori rendah.
\end{abstract}

Kata kunci: kerentanan pesisir, metode CVI, Pulau Bintan 


\section{PENDAHULUAN}

Kawasan pesisir merupakan wilayah yang sangat dinamis, unik, dan kompleks karena menjadi zona transisi dan interaksi antara daratan, perairan, dan atmosfer. Interaksi tersebut menjadikan kawasan pesisir memiliki potensi sumberdaya hayati dan non-hayati yang besar sehingga menjadi sasaran untuk pengembangan aktivitas masyarakat seperti pemukiman, industri, pelabuhan, perikanan tangkap, pertambakan, pertanian serta pariwisata (Bukvic et al. 2020; Dhiauddin \& Gemilang 2018; Giambastiani et al. 2017; Hamuna et al. 2018; Reimann et al. 2018; Rizzo et al. 2020; Ward et al. 2011). Di sisi lain, interaksi ini menyebabkan wilayah pesisir selalu mengalami perubahan profil yang merupakan kemampuan alami pesisir untuk terus berada dalam kondisi kesetimbangan alami dan juga menyebabkan kawasan pesisir menjadi kawasan paling rentan di Bumi (Field et al. 2014; Imran et al. 2020; Suhana et al. 2016). Kawasan pesisir dengan tingkat kerentanan tinggi dapat menyebabkan potensi kawasan pesisir seperti pariwisata bahari maupun perikanan tidak dapat dimanfaatkan secara optimal dan berkelanjutan dalam periode yang lama. Kerentanan pesisir dapat disebabkan secara alami seperti pengaruh meteorologi oseanografi (met-ocean) seperti angin, pasang surut, gelombang, gelombang badai, tsunami, bencana alam seperti banjir bandang, dan curah hujan yang tinggi. Selain faktor alami, aktivitas manusia, kepadatan penduduk yang tinggi dan sistem sosial ekonomi yang besar serta kegiatan antropogenik seperti pembangunan struktur pantai secara terus menerus juga dapat menjadi faktor yang menyebabkan tingkat kerentanan suatu kawasan pesisir menjadi tinggi (Kumar \& Kunte 2012; Islam et al. 2016; Chandrasekar 2013; Mahmood et al. 2020; Rajasree \& Deo 2020; Reiners \& Driese 2001; Yin et al. 2012).

Manajemen pengelolaan kawasan pesisir harus dilandasi prinsip perlindungan dan pelestarian lingkungan dapat untuk menjaga agar pemanfaatan kawasan pesisir tidak menyebabkan kerusakan pada kawasan tersebut (Angkotasan et al. 2012). Mengetahui potensi yang dimiliki suatu kawasan pesisir, tingkat kesesuaian pengelolaan potensi kawasan pesisir merupakan salah satu bentuk manajemen pengelolaan kawasan pesisir dengan prinsip perlindungan dan pelestarian lingkungan. Selain hal-hal yang telah disebutkan sebelumnya, mengetahui seberapa besar tingkat kerentanan kawasan tersebut dan faktor apa saja yang mempengaruhi tingkat kerentanannya juga menjadi salah satu hal yang diperlukan dalam menerapkan prinsip perlindungan dan pelestarian lingkungan dalam pengelolaan kawasan pesisir (Sekovski et al. 2020). Banyak penelitian yang telah dilakukan mengenai kerentanan kawasan pesisir di dunia maupun Indonesia. Dari penelitian-penelitian tersebut dapat ditarik satu kesimpulan bahwa banyak faktor yang dapat menyebabkan kerentanan kawasan pesisir (Hamuna et al. 2018; Handartoputra et al. 2015; Joesidawati 2016), tidak terkecuali pesisir utara dan timur Pulau Bintan.

Sebagai salah satu kawasan pesisir, pesisir utara dan timur Pulau Bintan juga terdapat banyak aktivitas pemanfaatan potensi yang dimiliki. Pesisir utara dan timur Pulau Bintan dimanfaatkan sebagai kawasan permukiman, wilayah konservasi padang lamun serta pariwisata. Sektor pariwisata merupakan aktivitas paling dominan di pesisir utara dan timur Pulau Bintan hal ini dapat dilihat dari begitu banyaknya fasilitas pendukung kegiatan pariwisata seperti hotel dan resort yang dibangun di sepanjang pantai utara dan timur Pulau Bintan (Irawan et al. 2018; Suhana et al. 2016, 2018) dan masih terus berkembang. Penelitian mengenai kerentanan pesisir di pantai timur Pulau Bintan pernah dilakukan oleh Suhana et al. (2016), dari hasil penelitian tersebut disimpulkan bahwa tingkat kerentanan pantai timur Pulau Bintan berada dalam kategori rendah. Dengan kondisi sektor pariwisata yang masih terus berkembang di pesisir utara dan timur Pulau Bintan, maka dirasa perlu untuk melakukan kembali studi mengenai bagaimana tingkat kerentanan pesisir di utara dan timur Pulau Bintan untuk mengetahui apakah saat ini tingkat kerentanan pesisir di utara dan timur Pulau Bintan telah mengalami perubahan dari tahun 2016.

Perbedaan pada penelitian sebelumnya terdapat pada parameter yang digunakan serta lokasi penelitian. Penelitian pada tahun 2016 dilakukan di pantai timur Pulau Bintan dengan menggunakan 5 (lima) parameter penilaian yaitu geomorfologi pantai, perubahan garis pantai, kemiringan pantai, tunggang pasang surut, dan gelombang laut. Penelitian kali ini dilakukan 
di pantai timur dan utara Pulau Bintan. Alasan penambahan lokasi penelitian dibandingkan dengan penelitian pada tahun 2016 adalah bahwa pantai utara Pulau Bintan memiliki potensi dan bentuk pemanfaatan yang sama yaitu sebagai kawasan pariwisata. Selain itu penelitian kali ini menggunakan 7 (tujuh) parameter penilaian yaitu geomorfologi pantai, perubahan garis pantai, kemiringan pantai, kenaikan muka air laut relatif, ketinggian permukaan tanah, tunggang pasang surut, dan gelombang laut.

\section{METODE PENELITIAN}

\section{Lokasi penelitian}

Penelitian dilaksanakan pada bulan Agustus-Oktober tahun 2020. Lokasi penelitian berada di sepanjang pantai utara dan timur Pulau Bintan yang membentang sepanjang $\pm 117,61 \mathrm{~km}$ di sekitar 1 (satu) kelurahan dan 7 (tujuh) desa yaitu Kelurahan Kawal, Desa Teluk Bakau, Desa Malang Rapat, Desa Berakit, Desa Pengudang, Desa Sri Bintan, Desa Sebong Lagoi, dan Desa Sebong Pereh (Gambar 1). Beberapa lokasi penelitian memiliki kesamaan lokasi dengan lokasi penelitian yang dilakukan oleh Suhana et al. (2016) di pesisir timur Pulau Bintan, namun pada penelitian ini lokasi penelitian diperluas hingga ke pesisir utara Pulau Bintan dengan pertimbangan bahwa pesisir utara Pulau Bintan juga merupakan kawasan dengan pemanfaatan yang sama dengan pesisir timur Pulau Bintan yaitu sebagai kawasan pariwisata dan kawasan konservasi padang lamun. Kesamaan/ padanan lokasi penelitian dengan lokasi penelitian yang dilakukan oleh Suhana et al. (2016) disajikan pada Tabel 1.

\section{Alat, bahan, dan metode}

Penelitian ini menggunakan metode survei dengan teknik purposive sampling untuk penentuan lokasi pengamatan/ pengambilan data di lapangan. Pengamatan geomorfologi dilakukan di 29 (dua puluh sembilan) titik pengamatan, pengukuran pasang surut dilakukan di 8 (delapan) titik pengukuran, dan 8 (delapan) titik pengukuran kemiringan pantai. Data-data yang diambil di lapangan terdiri dari kondisi geomorfologi, sedimen, dan pasang surut sedangkan beberapa data lain diperoleh dari unduhan di beberapa laman penyedia data secara online.

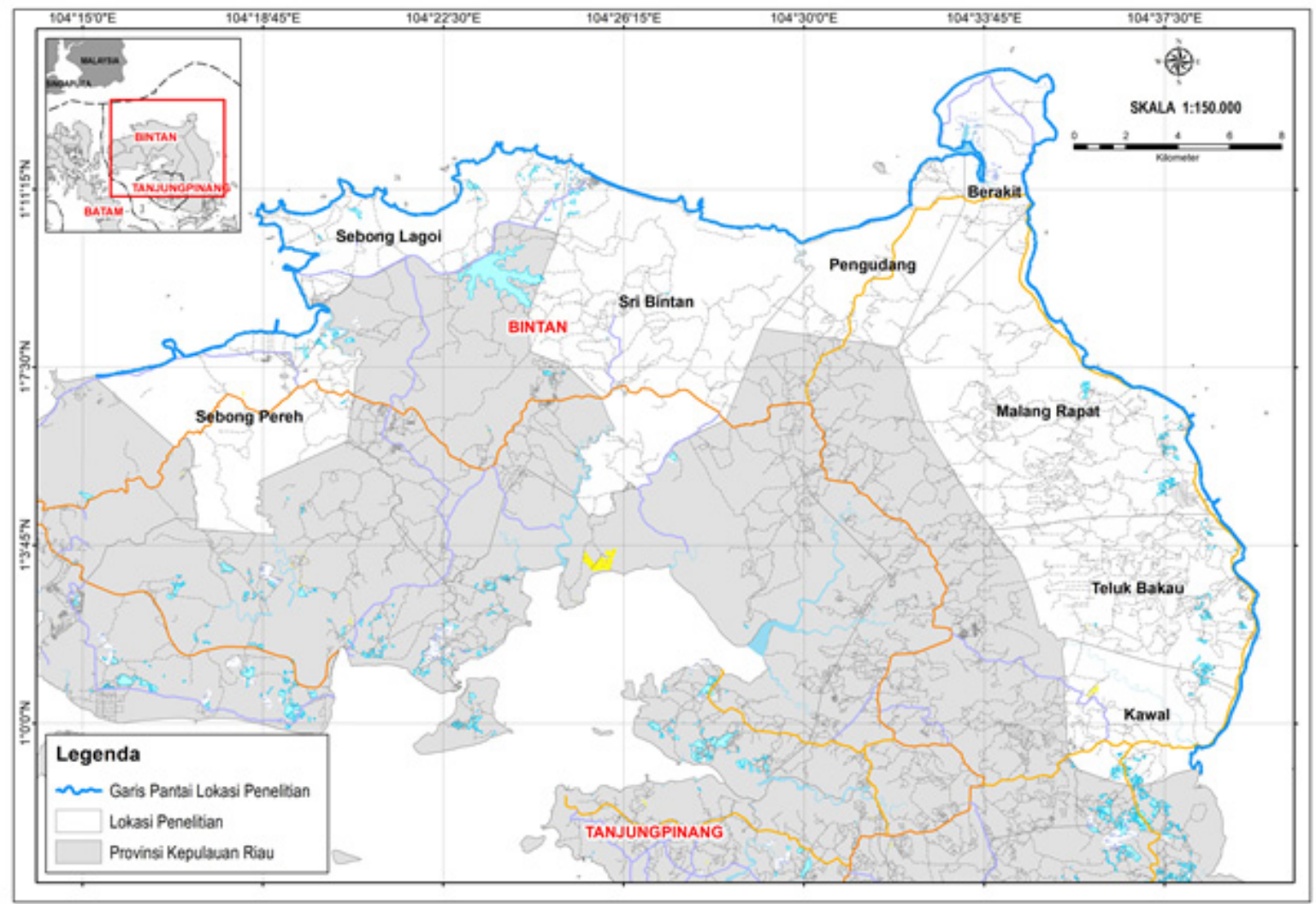

Gambar 1. Peta lokasi kawasan pesisir yang menjadi area penelitian 
Tabel 2. Parameter penilaian kerentanan pantai

\begin{tabular}{|c|c|c|c|c|c|c|c|}
\hline \multirow{3}{*}{ No. } & \multirow{3}{*}{ Variabel } & \multicolumn{5}{|c|}{ Bobot dan Skor } & \multirow{3}{*}{ Satuan } \\
\hline & & $\begin{array}{l}\text { Sangat } \\
\text { Rendah }\end{array}$ & Rendah & Sedang & Tinggi & $\begin{array}{l}\text { Sangat } \\
\text { Tinggi }\end{array}$ & \\
\hline & & 1 & 2 & 3 & 4 & 5 & \\
\hline 1. & $\begin{array}{l}\text { Geomorfologi } \\
\text { pantai }^{3}\end{array}$ & $\begin{array}{c}\text { Pantai } \\
\text { bertebing } \\
\text { berbatu }\end{array}$ & $\begin{array}{c}\text { Pantai } \\
\text { bertebing } \\
\text { menengah, } \\
\text { Pantai } \\
\text { berbatu }\end{array}$ & $\begin{array}{l}\text { Pantai } \\
\text { bertebing } \\
\text { rendah } \\
\text { berbatu, } \\
\text { dataran } \\
\text { aluvial }\end{array}$ & $\begin{array}{c}\text { Pantai } \\
\text { berbatu } \\
\text { kerikil, } \\
\text { estuari, } \\
\text { laguna }\end{array}$ & $\begin{array}{c}\text { Pantai } \\
\text { berpasir, } \\
\text { rawa payau, } \\
\text { mangrove, } \\
\text { terumbu } \\
\text { karang, } \\
\text { delta, } \\
\text { berlumpur, } \\
\text { lamun }\end{array}$ & - \\
\hline 2. & $\begin{array}{l}\text { Abrasi (-) / } \\
\text { Akresi (+) }_{\text {pantai }^{2}}\end{array}$ & $>2,00$ & $\begin{array}{l}1,00 \mathrm{~s} / \mathrm{d} \\
2,00\end{array}$ & $\begin{array}{c}-1,00 \mathrm{~s} / \mathrm{d} \\
1,00\end{array}$ & $\begin{array}{l}-2,00 \\
\mathrm{~s} / \mathrm{d} \\
-1,00\end{array}$ & $<-2,00$ & $\begin{array}{c}\mathrm{m} / \\
\text { tahun }\end{array}$ \\
\hline 3. & $\begin{array}{l}\text { Kemiringan } \\
\text { pantai }^{4}\end{array}$ & $>1,90$ & $>1,30-1,90$ & $\begin{array}{c}>0,90- \\
1,30\end{array}$ & $\begin{array}{c}0,60- \\
0,90\end{array}$ & $<0,60$ & $\%$ \\
\hline 4. & $\begin{array}{l}\text { Ketinggian } \\
\text { permukaan } \\
\text { tanah }^{2}\end{array}$ & $>30,00$ & $\begin{array}{c}>20,00- \\
30,00\end{array}$ & $\begin{array}{c}>10,00- \\
20,00\end{array}$ & $\begin{array}{c}>5,00- \\
10,00\end{array}$ & $0,00-5,00$ & $\mathrm{~m}$ \\
\hline 5. & $\begin{array}{l}\text { Perubahan } \\
\text { muka air } \\
\text { laut relatif }{ }^{1}\end{array}$ & $<-1,00$ & $\begin{array}{c}-1,00 \mathrm{~s} / \mathrm{d} \\
0,90\end{array}$ & $\begin{array}{c}>0,90 \mathrm{~s} / \mathrm{d} \\
2,00\end{array}$ & $\begin{array}{c}>2,00 \\
\text { s/d } \\
4,00\end{array}$ & $>4,00$ & $\begin{array}{l}\mathrm{mm} / \\
\text { tahun }\end{array}$ \\
\hline 6. & $\begin{array}{l}\text { Tinggi } \\
\text { gelombang } \\
\text { laut rata- } \\
\text { rata }^{4}\end{array}$ & $<1,10$ & $\begin{array}{c}1,10 \mathrm{~s} / \mathrm{d} \\
2,00\end{array}$ & $\begin{array}{c}>2,00 \mathrm{~s} / \mathrm{d} \\
2,25\end{array}$ & $\begin{array}{c}>2,25 \\
s / d \\
2,60\end{array}$ & $>2,60$ & $\mathrm{~m}$ \\
\hline 7. & $\begin{array}{l}\text { Kisaran } \\
\text { tunggang } \\
\text { pasang } \\
\text { surut }^{1}\end{array}$ & $<0,50$ & $\begin{array}{c}0,50 \mathrm{~s} / \mathrm{d} \\
1,90\end{array}$ & $\begin{array}{c}>1,90 \mathrm{~s} / \mathrm{d} \\
4,00\end{array}$ & $\begin{array}{c}>4,00 \\
\text { s/d } \\
6,00\end{array}$ & $>6,00$ & $\mathrm{~m}$ \\
\hline
\end{tabular}

Sumber: Handartoputra et al. $(2015)^{3}$; Joesidawati $(2016)^{2}$; Royo et al. $(2016)^{2}$; Thieler \& Hammar-Klose (2000) ${ }^{1}$

Tabel 3. Kategori kerentanan pesisir berdasarkan nilai CVI

\begin{tabular}{cc}
\hline Nilai CVI & Kategori Kerentanan \\
\hline $0,38-<4,28$ & Sangat Rendah \\
$4,28-<17,68$ & Rendah \\
$17,68-<48,38$ & Sedang \\
$48,38-<105,64$ & Tinggi \\
105,64 & Sangat Tinggi \\
\hline
\end{tabular}


Tabel 4. Perbedaan dan persamaan variabel yang digunakan dengan penelitian tahun 2016 oleh Suhana et al. (2016)

\begin{tabular}{lcc}
\hline \multicolumn{1}{c}{ Variabel yang Digunakan } & Tahun 2020 & Tahun 2016 oleh Suhana et al. (2016) \\
\hline Geomorfologi pantai & $\sqrt{ }$ & $\sqrt{ }$ \\
Perubahan garis pantai & $\sqrt{ }$ & $\sqrt{ }$ \\
Kemiringan pantai & $\sqrt{ }$ & - \\
Ketinggian permukaan tanah & $\sqrt{ }$ & - \\
Perubahan muka air laut relatif & $\sqrt{ }$ & $\sqrt{ }$ \\
Tinggi gelombang laut rata-rata & $\sqrt{ }$ & $\sqrt{ }$ \\
Kisaran tunggang pasang surut & $\sqrt{ }$ & \\
\hline
\end{tabular}

\section{HASIL DAN PEMBAHASAN}

\section{Hasil}

Hasil penelitian menunjukkan geomorfologi pesisir utara dan timur Pulau Bintan berupa pantai berpasir, berlumpur, dan berbatu (Gambar 2). Berdasarkan profil geomorfologi tersebut tingkat kerentanan pesisir utara dan timur Pulau Bintan berada pada kisaran kategori rendah dan sangat tinggi. Kondisi tingkat kerentanan sangat tinggi terdapat pada wilayah pesisir dengan panjang garis pantai $80,90 \mathrm{~km}(68,79 \%)$ yang berada di sekitar pesisir Kelurahan Kawal, Desa Teluk Bakau, Desa Pengudang, Desa Sri Bintan, Desa Sebong Lagoi, dan Desa Sebong Pereh, sedangkan kondisi tingkat kerentanan rendah berada di sekitar pesisir Desa Malang Rapat dan Desa Berakit dengan panjang garis pantai $36,70 \mathrm{~km}$ $(31,21 \%)$. Dari hasil yang diperoleh pada penelitian ini terdapat sedikit perbedaan dengan hasil penelitian yang dilakukan oleh Suhana et al. (2016) untuk variabel yang sama. Perbedaan ditemukan pada tingkat kerentanan yang diperoleh untuk wilayah Desa Malang Rapat dan Desa Berakit (Pantai Trikora 4 untuk penelitian yang dilakukan oleh Suhana et al. (2016)). Pada penelitian ini diketahui bahwa geomorfologi pantai Desa Malang Rapat dan Desa Berakit merupakan pantai berbatu sedangkan pada penelitian Suhana et al. (2016) di wilayah yang sama merupakan pantai dengan profil berupa pantai berbatu, berpasir, dan mangrove. Perbedaan ini menjadikan skor kerentanan yang diperoleh berbeda (Tabel 5). Perbedaan ini terjadi dapat disebabkan oleh titik pengamatan geomorfologi yang dilakukan berbeda dengan penelitian sebelumnya.

Tingkat kerentanan pesisir di utara dan timur Pulau Bintan berdasarkan kemiringan pantai berada pada kategori rendah-sangat tinggi. Kemiringan pantai di sekitar lokasi penelitian berada pada kisaran $0,18-1,73 \%\left(0,08-0,78{ }^{\circ}\right)$ dengan kemiringan rata-rata $0,97 \%\left(0,44^{\circ}\right)$ (Tabel 6). Kemiringan pantai utara dan timur Pulau Bintan termasuk dalam kategori datar $(<3,00 \%)$ (Kalay et al. 2018). Kemiringan pantai dengan kategori kerentanan rendah terdapat di sepanjang pantai Desa Berakit dan Desa Sri Bintan dengan kemiringan pantai masing-masing yaitu $1,63 \%(0,73$ $\left.{ }^{\circ}\right)$ dan $1,73 \%(0,78 \%$. Kemiringan pantai dengan kategori kerentanan sedang terdapat di sepanjang pantai Kelurahan Kawal dengan kemiringan pantai $0,94 \%\left(0,42{ }^{\circ}\right)$ dan Desa Sebong Lagoi dengan kemiringan pantai $1,20 \%(0,54 \%)$. Pesisir dengan tingkat kerentanan tinggi berdasarkan kondisi kemiringan pantai terdapat di sekitar Desa Teluk Bakau dan Desa Malang Rapat dengan tingkat kemiringan masingmasing yaitu $0,81 \%\left(0,36{ }^{\circ}\right)$ dan $0,87 \%$ $\left(0,39^{\circ}\right)$, sedangkan daerah dengan tingkat kerentanan sangat tinggi berdasarkan kemiringan pantai terdapat di sekitar Desa Pengudang dengan kemiringan pantai 0,18 $\%\left(0,08^{\circ}\right)$ dan Desa Sebong Pereh dengan kemiringan $0,40 \%\left(0,18^{\circ}\right)$.

Terdapat perbedaan hasil pengukuran pada tahun 2020 dengan tahun 2016 yang dilakukan oleh Suhana et al. (2016). Perbedaan ini terjadi disebabkan penelitian yang dilakukan oleh Suhana et al. (2016) merupakan nilai rataan kemiringan pada masing-masing pantai (Pantai Trikora 1-Pantai Trikora 4) sedangkan pada penelitian tahun 2020 kemiringan pantai yang dihitung adalah kemiringan pantai pada masing-masing desa pesisir di sepanjang keempat pantai yang menjadi lokasi penelitian Suhana et al. (2016). Faktor lain yang menyebabkan perbedaan adalah perbedaan lokasi pengukuran tingkat kemiringan pantai yang dilakukan. 
Perbedaan hasil pengukuran kemiringan pantai dengan hasil yang diperoleh pada penelitian sebelumnya disajikan pada Tabel 6.

Selain kemiringan pantai, elevasi permukaan tanah di kawasan pesisir juga memberikan pengaruh terhadap tingkat kerentanan di kawasan pesisir. Secara keseluruhan ketinggian permukaan tanah di masing-masing lokasi penelitian berada pada kisaran 0,00-193,85 m (Gambar 3), sedangkan ketinggian permukaan tanah sekitar $100 \mathrm{~m}$ dari garis pantai ke arah darat berada pada kisaran 1,06-4,06 m. Kisaran ketinggian tersebut menunjukkan tingkat kerentanan pesisir di utara dan timur Pulau Bintan berdasarkan ketinggian permukaan tanah berada pada kategori kerentanan sangat tinggi. Oleh sebab itu, hasil analisis elevasi permukaan tanah di kawasan pesisir utara dan timur Pulau Bintan cenderung sangat rentan terhadap segala faktor yang dapat menyebabkan kerusakan pada kawasan pesisir.

Dari hasil penelitian yang diperoleh pada tahun 2020 dengan hasil penelitian pada tahun 2016 yang dilakukan oleh Suhana et al. (2016) variabel kerentanan yang memiliki simpulan yang sama adalah

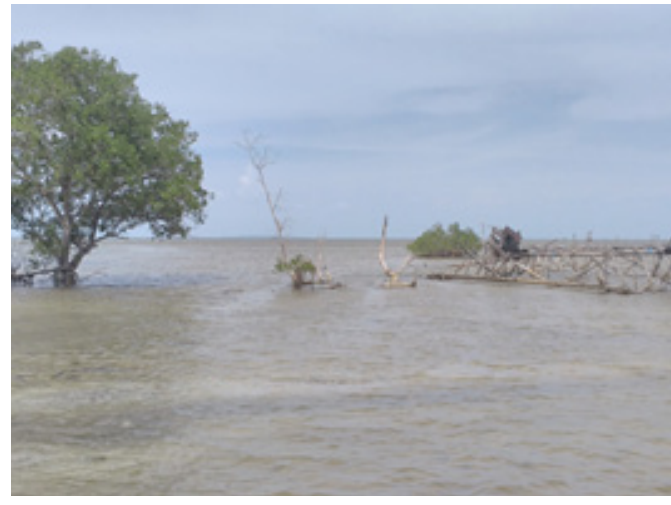

Desa Berakit

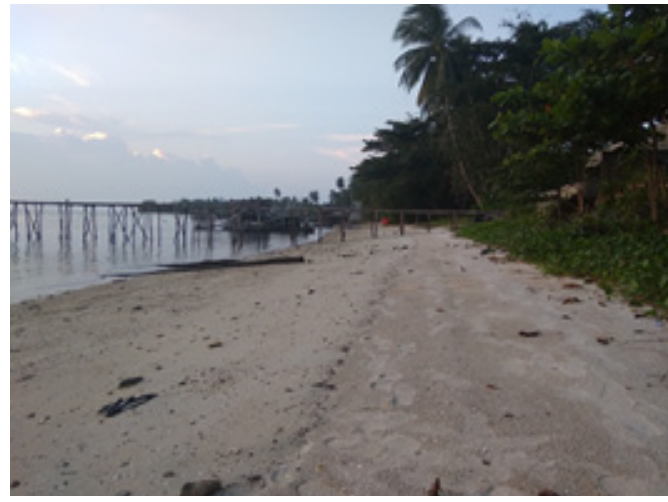

Kelurahan Kawal variabel tinggi gelombang laut rata-rata dan tunggang pasang surut. Pada kedua variabel ini memiliki kategori rendah dan sangat rendah. Kedua variabel ini merupakan variabel dengan skor kerentanan paling rendah, baik di tahun 2020 maupun di tahun 2016. Pada tahun 2020 kisaran tinggi gelombang laut rata-rata di lokasi penelitian adalah 1,34-1,50 $\mathrm{m} /$ tahun sedangkan pada tahun 2016 diperoleh kisaran tinggi gelombang laut per tahun adalah 0,44-0,72 m (Tabel 7). Sedangkan pada variabel tunggang pasang surut pada tahun 2020 berada kisaran 0,95-1,34 m sedangkan pada tahun 2016 nilai tunggang pasang surut adalah 0,71 $\mathrm{m}$ (Tabel 7). Terdapat kondisi dimana terjadi kenaikan pada kisaran tinggi gelombang laut maupun tunggang pasang surut di lokasi penelitian. $\mathrm{Hal}$ ini memungkinkan terjadi mengingat saat ini pemanasan global semakin tinggi yang menyebabkan terjadinya pencairan es di daerah kutub sehingga menyebabkan naiknya volume air laut. Oleh sebab itu fenomena ini diduga menjadi penyebab naiknya kisaran tunggang pasang surut dan tinggi gelombang laut rata-rata di lokasi penelitian pada tahun 2020 .

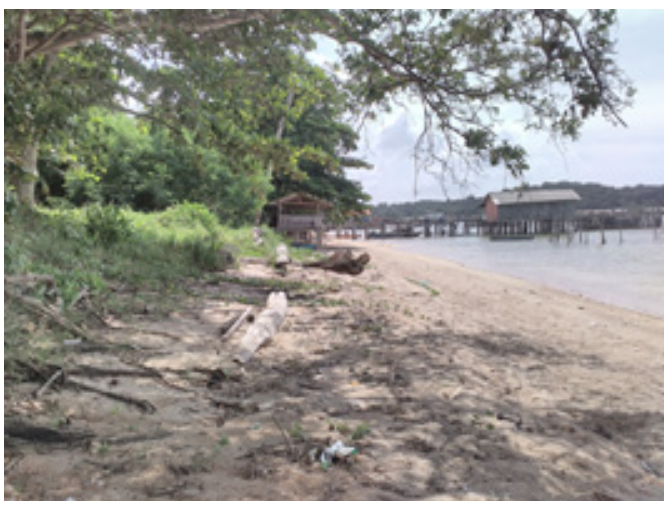

Desa Teluk Bakau

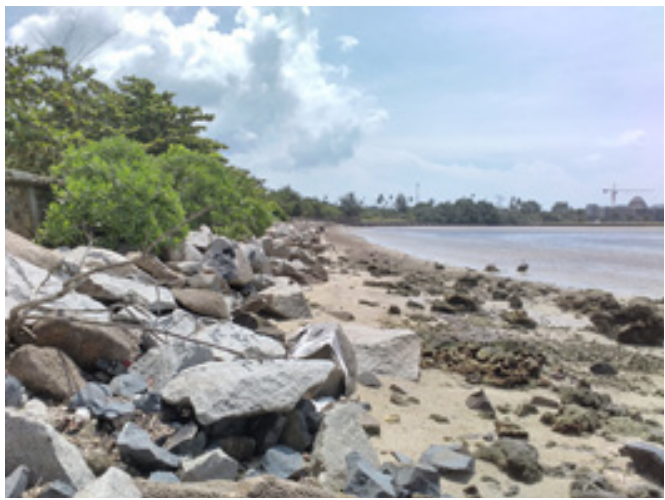

Desa Malang Rapat

Gambar 2. Profil geomorfologi pesisir di beberapa titik lokasi penelitian 
Tabel 5. Perbandingan skor kerentanan pesisir dari variabel geomorfologi pantai tahun 2020 dengan tahun 2016 yang dilakukan oleh Suhana et al. (2016)

\begin{tabular}{|c|c|c|c|c|c|c|c|}
\hline \multicolumn{4}{|c|}{ Tahun 2020} & \multicolumn{4}{|c|}{ Tahun 2016 oleh Suhana et al. (2016) } \\
\hline Lokasi & $\begin{array}{c}\text { Kondisi } \\
\text { GEO }\end{array}$ & Skor & Kategori & Lokasi & Kondisi GEO & Skor & Kategori \\
\hline $\begin{array}{l}\text { Kelurahan } \\
\text { Kawal }\end{array}$ & Berpasir & 5 & $\begin{array}{l}\text { Sangat } \\
\text { Tinggi }\end{array}$ & $\begin{array}{c}\text { Pantai } \\
\text { Trikora } 1\end{array}$ & $\begin{array}{l}\text { Berpasir, } \\
\text { Mangrove }\end{array}$ & 5 & $\begin{array}{l}\text { Sangat } \\
\text { Tinggi }\end{array}$ \\
\hline $\begin{array}{l}\text { Desa Teluk } \\
\text { Bakau }\end{array}$ & Berpasir & 5 & $\begin{array}{l}\text { Sangat } \\
\text { Tinggi }\end{array}$ & $\begin{array}{c}\text { Pantai } \\
\text { Trikora } 2\end{array}$ & Berpasir & 5 & $\begin{array}{l}\text { Sangat } \\
\text { Tinggi }\end{array}$ \\
\hline $\begin{array}{c}\text { Desa Malang } \\
\text { Rapat }\end{array}$ & Berbatu & 2 & Rendah & $\begin{array}{c}\text { Pantai } \\
\text { Trikora } 3\end{array}$ & $\begin{array}{l}\text { Berpasir, } \\
\text { Berbatu, dan } \\
\text { Mangrove }\end{array}$ & 4 & Tinggi \\
\hline Desa Berakit & Berbatu & 2 & Rendah & $\begin{array}{c}\text { Pantai } \\
\text { Trikora } 4\end{array}$ & $\begin{array}{l}\text { Berpasir, } \\
\text { Mangrove }\end{array}$ & 5 & $\begin{array}{l}\text { Sangat } \\
\text { Tinggi }\end{array}$ \\
\hline $\begin{array}{c}\text { Desa } \\
\text { Pengudang }\end{array}$ & Berpasir & 5 & $\begin{array}{l}\text { Sangat } \\
\text { Tinggi }\end{array}$ & - & - & - & - \\
\hline $\begin{array}{l}\text { Desa Sri } \\
\text { Bintan }\end{array}$ & Berpasir & 5 & $\begin{array}{l}\text { Sangat } \\
\text { Tinggi }\end{array}$ & - & - & - & - \\
\hline $\begin{array}{l}\text { Desa Sebong } \\
\text { Lagoi }\end{array}$ & Berpasir & 5 & $\begin{array}{l}\text { Sangat } \\
\text { Tinggi }\end{array}$ & - & - & - & - \\
\hline $\begin{array}{c}\text { Desa Sebong } \\
\text { Pereh }\end{array}$ & Berpasir & 5 & $\begin{array}{l}\text { Sangat } \\
\text { Tinggi }\end{array}$ & - & - & - & - \\
\hline
\end{tabular}

Keterangan: GEO: Geomorfologi pantai; untuk padanan/kesamaan lokasi lebih jelas dapat dilihat pada Tabel 1 .

Tabel 6. Perbandingan skor kerentanan pesisir dari variabel kemiringan pantai tahun 2020 dengan tahun 2016 yang dilakukan oleh Suhana et al. (2016)

\begin{tabular}{|c|c|c|c|c|c|c|c|}
\hline \multicolumn{4}{|c|}{ Tahun 2020} & \multicolumn{4}{|c|}{ Tahun 2016 oleh Suhana et al. (2016) } \\
\hline Lokasi & KPT (\%) & Skor & Kategori & Lokasi & KPT (\%) & Skor & Kategori \\
\hline $\begin{array}{l}\text { Kelurahan } \\
\text { Kawal }\end{array}$ & 0,94 & 3 & Sedang & $\begin{array}{c}\text { Pantai } \\
\text { Trikora } 1\end{array}$ & 0,16 & 5 & $\begin{array}{c}\text { Sangat } \\
\text { Tinggi }\end{array}$ \\
\hline $\begin{array}{c}\text { Desa Teluk } \\
\text { Bakau }\end{array}$ & 0,81 & 4 & Tinggi & $\begin{array}{c}\text { Pantai } \\
\text { Trikora } 2\end{array}$ & 0,28 & 5 & $\begin{array}{l}\text { Sangat } \\
\text { Tinggi }\end{array}$ \\
\hline $\begin{array}{c}\text { Desa Malang } \\
\text { Rapat }\end{array}$ & 0,87 & 4 & Tinggi & $\begin{array}{c}\text { Pantai } \\
\text { Trikora } 3\end{array}$ & 0,22 & 5 & $\begin{array}{l}\text { Sangat } \\
\text { Tinggi }\end{array}$ \\
\hline Desa Berakit & 1,63 & 2 & Rendah & $\begin{array}{c}\text { Pantai } \\
\text { Trikora } 4\end{array}$ & 0,17 & 5 & $\begin{array}{l}\text { Sangat } \\
\text { Tinggi }\end{array}$ \\
\hline $\begin{array}{c}\text { Desa } \\
\text { Pengudang }\end{array}$ & 0,18 & 5 & $\begin{array}{l}\text { Sangat } \\
\text { Tinggi }\end{array}$ & - & - & - & - \\
\hline $\begin{array}{l}\text { Desa Sri } \\
\text { Bintan }\end{array}$ & 1,73 & 2 & Rendah & - & - & - & - \\
\hline $\begin{array}{l}\text { Desa Sebong } \\
\text { Lagoi }\end{array}$ & 1,20 & 3 & Sedang & - & - & - & - \\
\hline $\begin{array}{c}\text { Desa Sebong } \\
\text { Pereh }\end{array}$ & 0,40 & 5 & $\begin{array}{l}\text { Sangat } \\
\text { Tinggi }\end{array}$ & - & - & - & - \\
\hline
\end{tabular}

Keterangan: GEO: Geomorfologi pantai; untuk padanan/kesamaan lokasi lebih jelas dapat dilihat pada Tabel 1 . 


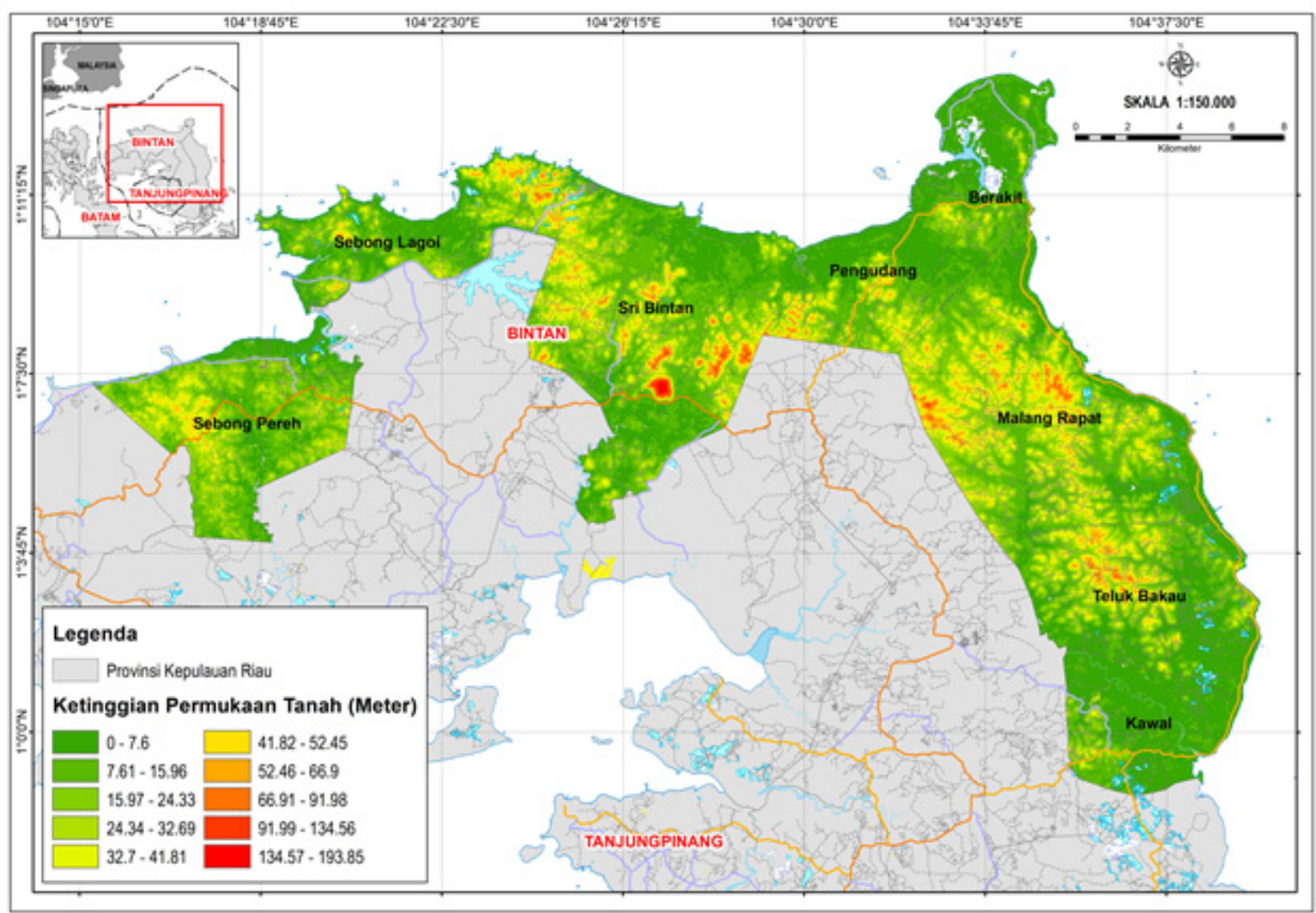

Gambar 3. Peta kondisi elevasi ketinggian permukaan tanah di lokasi penelitian

Tabel 7. Perbandingan skor kerentanan pesisir dari variabel tinggi gelombang laut rata-rata dan tunggang pasang surut tahun 2020 dengan tahun 2016 yang dilakukan oleh Suhana et al. (2016)

\begin{tabular}{|c|c|c|c|c|c|c|}
\hline \multirow{2}{*}{ Variabel } & \multicolumn{3}{|c|}{ Tahun 2020} & \multicolumn{3}{|c|}{$\begin{array}{c}\text { Tahun } 2016 \text { oleh Suhana et } \\
\text { al. (2016) }\end{array}$} \\
\hline & $\begin{array}{l}\text { Kisaran } \\
\text { Nilai }\end{array}$ & Skor & Kategori & $\begin{array}{c}\text { Kisaran } \\
\text { Nilai }\end{array}$ & Skor & Kategori \\
\hline $\begin{array}{l}\text { Tinggi gelombang laut rata- } \\
\text { rata (m/tahun) }\end{array}$ & $1,34-1,50$ & 2 & Rendah & $0,44-0,72$ & 1 & $\begin{array}{l}\text { Sangat } \\
\text { Rendah }\end{array}$ \\
\hline Tunggang pasang surut (m) & $0,95-1,34$ & 2 & Rendah & 0,71 & 1 & $\begin{array}{l}\text { Sangat } \\
\text { Rendah }\end{array}$ \\
\hline
\end{tabular}

Variabel lain yang dapat menentukan kerentanan pada suatu kawasan pesisir adalah proses perubahan garis pantai. Perubahan profil pantai merupakan salah satu indikator untuk mengetahui apakah suatu kawasan pesisir mengalami tekanan (Suhana et al. 2016). Perubahan garis pantai juga menunjukkan dinamika proses di kawasan pesisir (Aedla et al. 2015; Bagli et al. 2004). Berdasarkan hasil analisis perubahan garis pantai selama periode 1990-2020 (30 tahun), fenomena abrasi tertinggi terjadi di sekitar pantai Desa Sebong Lagoi dengan jarak pergeseran posisi garis pantai sejauh $197,16 \mathrm{~m}$ atau sekitar $6,57 \mathrm{~m} /$ tahun, sedangkan fenomena akresi/sedimentasi tertinggi terjadi di sekitar pantai Desa Berakit dengan jarak akresi sejauh 148,00 m atau sekitar 4,93 m/ tahun. Berdasarkan rataan perubahan garis pantai per tahun, Desa Sebong Lagoi, Desa Sri Bintan, dan Desa Malang Rapat sangat dominan mengalami abrasi, sedangkan Kelurahan Kawal, Desa Teluk Bakau, Desa Berakit, Desa Pengudang, dan Desa Sebong Pereh cenderung mengalami akresi (Tabel 8). Berdasarkan kondisi perubahan garis pantai per tahun, Desa Sebong Lagoi memiliki tingkat kerentanan sangat tinggi disebabkan pada daerah ini abrasi dapat terjadi hingga $2,18 \mathrm{~m} /$ tahun. Sementara itu, daerah dengan tingkat kerentanan rendah berdasarkan perubahan garis pantai per tahun adalah Desa Sebong Pereh dimana 
akresi di daerah ini dapat terjadi hingga $1,02 \mathrm{~m} /$ tahun.

Perbedaan hasil penelitian tahun 2020 dengan tahun 2016 yang dilakukan oleh Suhana et al. (2016) disajikan pada Tabel 8. Pada variabel perubahan garis pantai perbedaan terdapat pada lokasi dan tahun pengamatan. Pada tahun 2020 pengamatan perubahan garis pantai yang dilakukan adalah selama 30 tahun (19902020) sedangkan penelitian pada tahun 2016 pengamatan perubahan garis pantai yang dilakukan adalah selama 10 tahun (20052014). Pada tahun 2016 abrasi maksimum ditemukan pada Pantai Trikora 4 (Desa Malang Rapat-Desa Berakit pada penelitian tahun 2020) dengan jarak akresi mencapai $47,51 \mathrm{~m}$ atau $1,19 \mathrm{~m} /$ tahun (Suhana et al. 2016). Sedangkan pada tahun 2020 di Desa Malang Rapat cenderung mengalami abrasi dengan jarak abrasi hingga 0,10 $\mathrm{m} /$ tahun, sementara itu di Desa Berakit cenderung mengalami akresi dengan jarak abrasi mencapai 0,61 $\mathrm{m} /$ tahun. Untuk wilayah yang dominan mengalami akresi/ sedimentasi pada tahun 2016 ditemukan di Pantai Trikora 1 (Kelurahan Kawal pada penelitian tahun 2020) dengan jarak akresi hingga $91,57 \mathrm{~m}$ atau sekitar $3,25 \mathrm{~m} /$ tahun. Sedangkan pada tahun 2020 di lokasi yang sama jarak akresi mencapai 0,66 m/ tahun. Secara keseluruhan dari variabel perubahan garis pantai, kerentanan di pesisir utara dan timur Pulau Bintan berada pada kisaran kategori rendah-sangat tinggi, sementara pada penelitian tahun 2016 tingkat kerentan dengan variabel yang sama berada pada kisaran rendah-sedang.

Hasil analisis kerentanan yang diperoleh menunjukkan tingkat kerentanan pesisir timur Pulau Bintan tidak mengalami perubahan signifikan dibandingkan dengan hasil penelitian yang sama yang telah dilakukan oleh Suhana et al. (2016). Perbedaan hasil penelitian ditemukan pada kawasan pesisir di Kelurahan Kawal (Pantai Trikora 1 dan Pantai Trikora 2 pada tahun 2016). Tahun 2016 tingkat kerentanan pesisir berada dalam kategori rendah, sedangkan pada tahun 2020 tingkat kerentanan di kawasan tersebut mengalami kenaikan status menjadi kategori sedang. Hal yang diduga menjadi penyebab perubahan kategori tingkat kerentanan di kawasan tersebut adalah laju perubahan garis pantai pada tahun 2020. Pada tahun 2016 laju perubahan garis pantai per tahun di sekitar Kelurahan Kawal sebesar 3,25 m/ tahun, sedangkan pada tahun 2020 laju perubahan garis pantai di lokasi yang sama turun menjadi $0,66 \mathrm{~m} /$ tahun.

Tabel 8. Perbandingan skor kerentanan pesisir dari variabel perubahan garis pantai tahun 2020 dengan tahun 2016 yang dilakukan oleh Suhana et al. (2016)

\begin{tabular}{|c|c|c|c|c|c|c|c|}
\hline \multicolumn{4}{|c|}{ Tahun 2020} & \multicolumn{4}{|c|}{ Tahun 2016 oleh Suhana et al. (2016) } \\
\hline Lokasi & $\begin{array}{c}\text { PGP } \\
\text { (m/tahun) }\end{array}$ & Skor & Kategori & Lokasi & $\begin{array}{c}\text { PGP } \\
\text { (m/tahun) }\end{array}$ & Skor & Kategori \\
\hline $\begin{array}{l}\text { Kelurahan } \\
\text { Kawal }\end{array}$ & 0,66 & 3 & Sedang & $\begin{array}{l}\text { Pantai } \\
\text { Trikora } 1\end{array}$ & 3,25 & 2 & Rendah \\
\hline $\begin{array}{l}\text { Desa Teluk } \\
\text { Bakau }\end{array}$ & 0,59 & 3 & Sedang & $\begin{array}{c}\text { Pantai } \\
\text { Trikora } 2\end{array}$ & 2,08 & 2 & Rendah \\
\hline $\begin{array}{c}\text { Desa Malang } \\
\text { Rapat }\end{array}$ & $-0,10$ & 3 & Sedang & $\begin{array}{c}\text { Pantai } \\
\text { Trikora } 3\end{array}$ & 1,49 & 3 & Sedang \\
\hline Desa Berakit & 0,61 & 3 & Sedang & $\begin{array}{c}\text { Pantai } \\
\text { Trikora } 4\end{array}$ & 2,09 & 5 & Sedang \\
\hline $\begin{array}{c}\text { Desa } \\
\text { Pengudang }\end{array}$ & 0,31 & 3 & Sedang & - & - & - & - \\
\hline $\begin{array}{l}\text { Desa Sri } \\
\text { Bintan }\end{array}$ & $-0,67$ & 3 & Sedang & - & - & - & - \\
\hline $\begin{array}{c}\text { Desa Sebong } \\
\text { Lagoi }\end{array}$ & $-2,18$ & 5 & $\begin{array}{l}\text { Sangat } \\
\text { Tinggi }\end{array}$ & - & - & - & - \\
\hline $\begin{array}{c}\text { Desa Sebong } \\
\text { Pereh }\end{array}$ & 1,02 & 2 & Rendah & - & - & - & - \\
\hline
\end{tabular}

Keterangan: PGP: Perubahan garis pantai; untuk padanan/kesamaan lokasi lebih jelas dapat dilihat pada Tabel 1 . 
Perubahan kategori kerentanan juga ditemukan di sekitar Desa Berakit dan Desa Malang Rapat (Pantai Trikora 4 pada tahun 2016). Tahun 2016 kerentanan pesisir di sekitar kawasan tersebut berada pada kategori sedang, sedangkan pada tahun 2020 tingkat kerentanan turun menjadi kategori rendah. Laju perubahan garis pantai juga diduga menjadi faktor penyebab perubahan kondisi tingkat kerentanan di kawasan tersebut. Tahun 2016 laju abrasi mencapai $-1,19 \mathrm{~m} /$ tahun, sedangkan tahun 2020 laju abrasi turun hingga $-0,10 \mathrm{~m} /$ tahun (Tabel 9). Menurunnya laju abrasi di kawasan tersebut diduga merupakan hasil dari penanaman mangrove dan pembangunan water breaker di sepanjang pantai di Desa Malang Rapat dan Desa Berakit. Hal ini menyebabkan laju abrasi akibat pengaruh arus, gelombang laut maupun pasang surut menjadi tereduksi. Variabel yang paling mempengaruhi tingkat kerentanan juga memiliki kesamaan dengan tahun 2016 yaitu variabel geomorfologi dan kemiringan pantai, namun hasil penelitian pada tahun 2020 diperoleh satu variabel lain yang dapat mempengaruhi tingkat kerentanan yaitu laju perubahan garis pantai per tahun. Dari penelitian yang telah dilakukan diketahui bahwa laju perubahan garis pantai mengalami perubahan yang cukup signifikan baik fenomena abrasi maupun akresi. Hal inilah yang menyebabkan kategori kerentanan yang diperoleh mengalami perubahan kategori di beberapa lokasi.

Seperti yang telah dijelaskan sebelumnya bahwa tingkat kerentanan pesisir di utara dan timur Pulau Bintan berada dalam kategori rendah-sedang (Gambar 4). Sekitar 57,68 \% wilayah pesisir utara dan timur Pulau Bintan berada dalam kategori sedang yang meliputi wilayah pesisir Kelurahan Kawal, Desa Teluk Bakau, Desa Pengudang, Desa Sebong Lagoi, dan Desa Sebong Pereh, sedangkan wilayah dengan kategori kerentanan rendah berada di sekitar pesisir Desa Malang Rapat, Desa Berakit, dan Desa Sri Bintan dengan persentase 42,32 \%. Skor kerentanan pesisir di utara dan timur Pulau Bintan berada pada kisaran 9,93-25,86 (Tabel 10). Wilayah dengan skor kerentanan tertinggi ditemukan di sekitar pesisir Desa Berakit, sedangkan wilayah dengan skor tertinggi ditemukan di sekitar pesisir Desa Pengudang.

Tabel 9. Karakteristik variabel kerentanan pesisir pada masing-masing lokasi

\begin{tabular}{|c|c|c|c|c|c|c|c|}
\hline \multirow[b]{2}{*}{ Lokasi } & \multicolumn{7}{|c|}{ Karakteristik Variabel Kerentanan } \\
\hline & GEO & $\begin{array}{c}\text { PGP } \\
\text { m/tahun }\end{array}$ & $\begin{array}{c}\mathbf{K P T} \\
\%\end{array}$ & $\underset{\mathbf{m}}{\mathbf{K T P}}$ & $\begin{array}{c}\text { PML } \\
\mathrm{mm} / \text { tahun }\end{array}$ & $\begin{array}{c}\text { TGL } \\
\text { m/tahun }\end{array}$ & $\begin{array}{c}\text { TPS } \\
\mathbf{m}\end{array}$ \\
\hline Kawal & Pantai Berpasir & 0,66 & 0,94 & 1,06 & 1,95 & 1,34 & 0,95 \\
\hline Teluk Bakau & Pantai Berpasir & 0,59 & 0,81 & 1,43 & 1,99 & 1,34 & 0,98 \\
\hline Malang Rapat & Pantai Berbatu & $-0,10$ & 0,87 & 1,87 & 1,97 & 1,41 & 1,03 \\
\hline Berakit & Pantai Berbatu & 0,61 & 1,63 & 3,09 & 1,95 & 1,50 & 1,10 \\
\hline Pengudang & Pantai Berpasir & 0,31 & 0,18 & 2,72 & 1,89 & 1,48 & 1,13 \\
\hline Sri Bintan & Pantai Berpasir & $-0,67$ & 1,73 & 2,89 & 1,81 & 1,49 & 1,18 \\
\hline Sebong Lagoi & Pantai Berpasir & $-2,18$ & 1,20 & 4,06 & 1,68 & 1,48 & 1,30 \\
\hline Sebong Pereh & Pantai Berpasir & 1,02 & 0,40 & 3,35 & 1,59 & 1,45 & 1,34 \\
\hline
\end{tabular}

Keterangan: GEO: Geomorfologi; PGP: Perubahan Garis Pantai; KPT: Kemiringan Pantai; KTP: Ketinggian Permukaan Tanah; PML: Perubahan Muka Laut; TGL: Tinggi Gelombang Laut; TPS: Tunggang Pasang Surut 


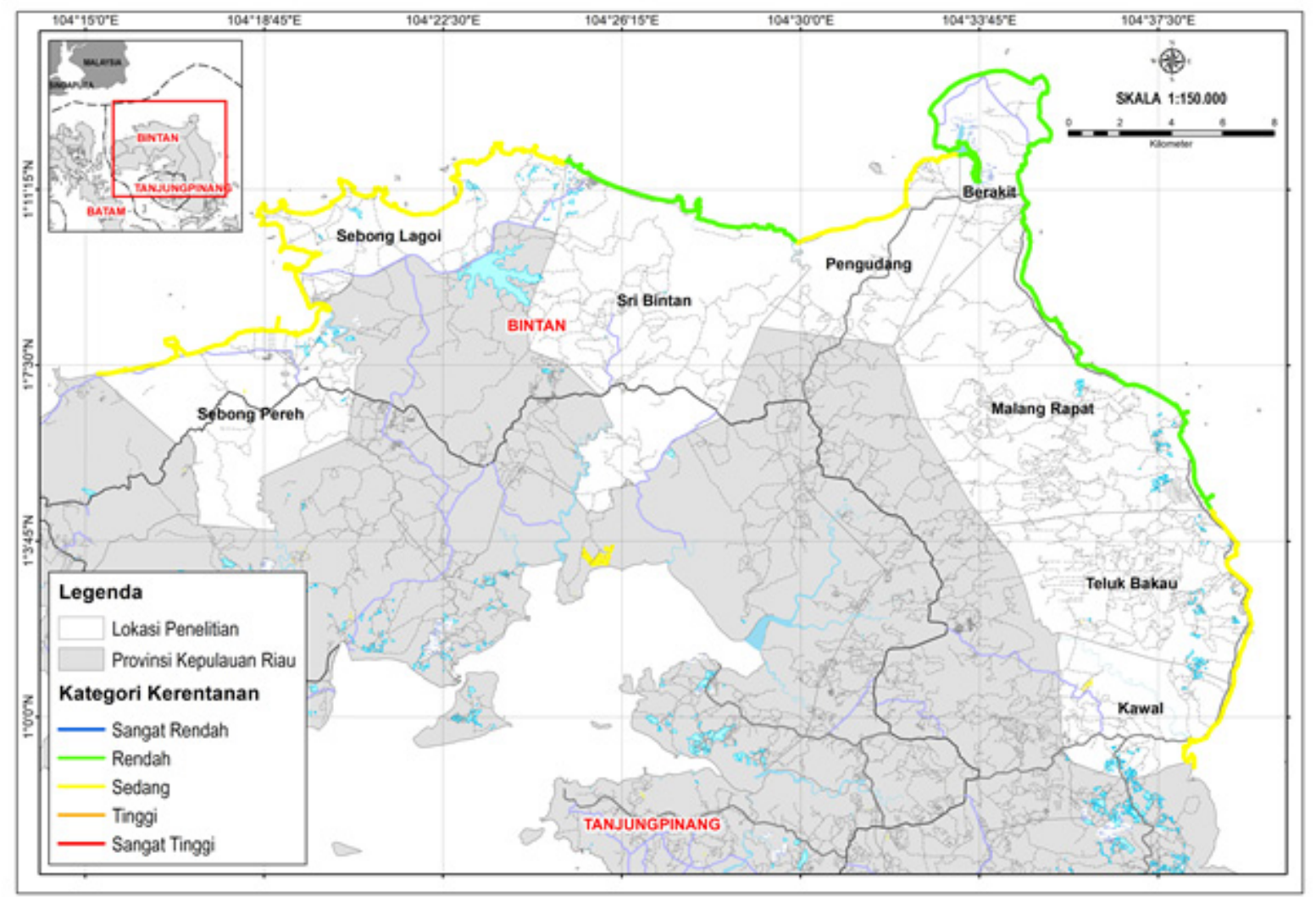

Gambar 4. Peta profil kerentanan pesisir di utara dan timur Pulau Bintan

Tabel 10. Hasil analisis kerentanan pesisir pada masing-masing lokasi penelitian

\begin{tabular}{|c|c|c|c|c|c|c|c|c|c|}
\hline \multirow{2}{*}{ Lokasi } & \multicolumn{7}{|c|}{ Skor Variabel Kerentanan } & \multirow{2}{*}{ Skor CVI } & \multirow{2}{*}{ Kategori } \\
\hline & GEO & PGP & KPT & KTP & PML & TGL & TPS & & \\
\hline Kawal & 5 & 3 & 3 & 5 & 3 & 2 & 2 & 19,64 & Sedang \\
\hline Teluk Bakau & 5 & 3 & 4 & 5 & 3 & 2 & 2 & 21,92 & Sedang \\
\hline Malang Rapat & 2 & 3 & 4 & 5 & 3 & 2 & 2 & 14,33 & Rendah \\
\hline Berakit & 2 & 3 & 2 & 5 & 3 & 2 & 2 & 9,93 & Rendah \\
\hline Pengudang & 5 & 3 & 5 & 5 & 3 & 2 & 2 & 25,86 & Sedang \\
\hline Sri Bintan & 5 & 3 & 2 & 5 & 3 & 2 & 2 & 15,78 & Rendah \\
\hline Sebong Lagoi & 5 & 5 & 3 & 5 & 3 & 2 & 2 & 24,45 & Sedang \\
\hline Sebong Pereh & 5 & 2 & 5 & 5 & 3 & 2 & 2 & 20,27 & Sedang \\
\hline
\end{tabular}

Keterangan: GEO: Geomorfologi; PGP: Perubahan Garis Pantai; KPT: Kemiringan Pantai; KTP: Ketinggian Permukaan Tanah; PML: Perubahan Muka Laut; TGL: Tinggi Gelombang Laut; TPS: Tunggang Pasang Surut

\section{Pembahasan}

Kerentanan pesisir merupakan suatu kondisi yang memberikan informasi berupa gambaran keadaan mudah terkena dari suatu sistem alami serta keadaan sosial pesisir (manusia, kelompok atau komunitas) terhadap bencana pantai (Dolan \& Walker 2006). Seperti yang telah dijelaskan sebelumnya bahwa tingkat kerentanan kawasan pesisir dapat disebabkan oleh berbagai macam faktor seperti proses alam, struktur profil kawasan pesisir itu sendiri maupun aktivitas manusia. Secara struktur profil kawasan pesisir, kemiringan pantai merupakan salah satu faktor penting dalam mempengaruhi kondisi kerentanan kawasan pesisir. Kemiringan pantai juga sangat mempengaruhi laju pengikisan profil pantai. Pantai dengan profil kemiringan datar atau landai cenderung akan lebih mudah dan lebih cepat mengalami proses pengikisan. Hal ini disebabkan pantai yang datar dan/ atau landai umumnya merupakan pantai 
berpasir dan pantai berlumpur, sehingga material sedimen penyusun pantai akan lebih mudah tergerus oleh proses fisika oseanografi (arus, gelombang, dan pasang surut) yang terjadi di sepanjang kawasan pantai (Handartoputra et al. 2015; Suhana et al. 2016; Suprapto et al. 2016).

Tingkat kerentanan merupakan suatu hal yang penting untuk diketahui karena dapat berpengaruh terhadap terjadinya bencana. Proporsi setiap kategori indeks kerentanan dapat menjadi petunjuk karakteristik spasial jenis variabel ataupun cakupan tingkat atau kategori kerentanan pada suatu kawasan. Proporsi ranking jenis variabel yang bervariasi menunjukkan bahwa keragaman karakteristik spasial variabel tersebut bersifat lokal (relatif) pada skala lokasi penilaian. Sebaliknya, apabila jenis ranking variabel yang hampir konstan atau konstan sepanjang garis pantai yang dinilai menunjukkan bahwa jenis variabel tersebut berkarakter regional hingga global (Kasim \& Siregar 2012). Penilaian kerentanan pesisir menggunakan berbagai variabel yang dianggap paling mempengaruhi perubahan kondisi kawasan pesisir. Variabel-variabel tersebut dapat dimodifikasi dan disesuaikan dengan lokasi yang diamati. Hal ini disebabkan kawasan pesisir di tiap wilayah memiliki kondisi dan profil yang berbeda (Hammar-Klose et al. 2003; Handartoputra et al. 2015; Joesidawati 2016; Koroglu et al. 2019; Royo et al. 2016).

Kawasan pesisir dengan elevasi permukaan tanah yang rendah akan cenderung menyebabkan tingkat kerentanan di suatu kawasan pesisir menjadi tinggi, hal ini disebabkan kawasan pesisir dengan elevasi permukaan tanah yang rendah dapat menyebabkan kawasan tersebut akan terendam air dan menyebabkan volume luas daratan berkurang apabila tinggi gelombang laut yang sampai ke pantai memiliki ketinggian yang lebih tinggi dari elevasi permukaan tanah di sekitar pesisir (Hamuna et al. 2018; Marwasta \& Priyono 2016). Tidak selamanya kawasan pesisir dengan elevasi permukaan tanah yang rendah akan selalu menyebabkan tingkat kerentanan di kawasan tersebut menjadi tinggi. Struktur dan profil geomorfologi juga dapat memberikan pengaruh apakah kawasan pesisir dengan elevasi permukaan yang rendah akan memiliki tingkat kerentanan pesisir yang tinggi ataupun rendah. Seperti yang dijelaskan oleh Hamuna et al. (2018) bahwa pantai dengan geomorfologi yang tersusun dari ekosistem mangrove dengan kerapatan tinggi akan cenderung memiliki tingkat kerentanan yang rendah, hal ini disebabkan ekosistem mangrove merupakan barrier (penghambat) utama untuk mereduksi efek hantaman arus dan gelombang laut ke pantai yang dapat menyebabkan profil penyusun pantai menjadi tergerus. Hal serupa juga dijelaskan oleh Handartoputra et al. (2015) dalam penelitiannya tentang geomorfologi pantai dengan profil pantai bertebing dan berbatu. Dijelaskan dalam penelitian tersebut bahwa pantai dengan profil bertebing dan berbatu yang terjal tinggi dan curam akan lebih tahan dalam menahan gelombang dan abrasi, sehingga mampu menjaga kondisi lingkungannya.

Secara keseluruhan diketahui bahwa variabel geomorfologi pantai, kemiringan pantai, dan ketinggian permukaan tanah menjadi variabel yang paling besar pengaruhnya terhadap tingkat kerentanan di pesisir utara dan timur Pulau Bintan. Walaupun secara keseluruhan tingkat kerentanan pesisir utara dan timur Pulau Bintan berada dalam kategori rendahsedang namun tetap terdapat beberapa variabel yang memiliki skor kerentanan dengan kategori sangat tinggi seperti geomorfologi pantai, kemiringan pantai dan ketinggian permukaan tanah. Halhal serupa juga ditemukan di beberapa penelitian serupa yang telah dilakukan di daerah pesisir lain di Indonesia seperti yang dilakukan oleh Gemilang et al. (2007) di daerah pesisir Sumatera Barat yang menjelaskan kondisi geomorfologi pesisir sangat mempengaruhi tingkat kerentanan pesisir di kawasan tersebut. Penelitian lain yang dilakukan oleh Handartoputra et al. (2015) di pesisir Pantai Sendag Biru, Kabupaten Malang menemukan bahwa variabel jarak vegetasi dari pantai dan tunggang pasang surut (tidal range) menjadi faktor yang paling mempengaruhi tingkat kerentanan di kawasan tersebut. Penelitian yang dilakukan oleh Joesidawati (2016) menjelaskan kondisi geomorfologi pantai, ketinggian permukaan tanah (topografi), kenaikan muka air laut relatif, serta lebar sabuk hijau menjadi variabel yang paling mempengaruhi tingkat kerentanan pesisir di pesisir Kabupaten Tuban, sedangkan Hamuna et al. (2018) menemukan bahwa variabel elevasi permukaan tanah menjadi variabel yang paling mempengaruhi tingkat kerentanan di pesisir kota dan kabupaten di Jayapura.

Melihat dari hasil penelitian yang 
diperoleh serta beberapa hasil penelitian serupa yang dilakukan di berbagai lokasi dapat disimpulkan bahwa begitu banyak faktor yang dapat menyebabkan kerentanan wilayah pesisir dan juga diperoleh informasi fakta nyata bahwa sebagian besar wilayah pesisir di Indonesia menghadapi berbagai tekanan yang menyebabkan kerentanan pesisir, tidak terkecuali pesisir utara dan timur Pulau Bintan. Terdapat beberapa variabel yang menyebabkan tingkat kerentanan pesisir di utara dan timur Pulau Bintan dapat menjadi sangat tinggi, namun seperti yang diketahui bahwa segala aspek dan proses fisik yang terjadi di kawasan pesisir saling mempengaruhi dan saling berkaitan, sehingga keseimbangan antara masing-masing variabel akan saling mempengaruhi tingkat kerentanan pesisir di utara dan timur Pulau Bintan. Oleh sebab itu, walaupun terdapat beberapa variabel dengan skor kerentanan sangat tinggi, namun dengan variabel lain yang memiliki kerentanan yang rendah menjadi reduksi tingkat kerentanan pesisir di utara dan timur Pulau Bintan.

Oleh sebab itu dari hasil penelitian ini diharapkan dapat menjadi acuan/ referensi bagi instansi/lembaga apapun yang berwenang terhadap pemanfaatan dan pengelolaan di kawasan pesisir utara dan timur Pulau Bintan untuk dapat memperhatikan beberapa faktor yang dapat menyebabkan meningkatnya tingkat kerentanan di pesisir utara dan timur Pulau Bintan seperti yang telah dijelaskan sebelumnya. Sangat disarankan agar pemanfaatan dan pengelolaan serta pembangunan kawasan di pesisir utara dan timur Pulau Bintan tidak lagi dilakukan di sepanjang pantai seperti yang sedang berjalan selama ini. Hal ini tentunya akan menyebabkan alih fungsi lahan/kawasan pantai yang pasti akan menggangu, mengubah bahkan mungkin merusak struktur profil pantai/pesisir bahkan ekosistem pesisir disekitarnya. Fenomena meningkatnya kerentanan pesisir di suatu kawasan akibat alih fungsi lahan sudah terjadi di sekitar pesisir Garut Selatan, Provinsi Jawa Barat (Suprapto et al. 2016). Pada penelitian di lokasi tersebut dijelaskan alih fungsi lahan ekosistem mangrove menjadi kawasan pariwisata, kebun campuran, dan lahan pertanian menyebabkan tingkat kerentanan pesisir di Garut Selatan meningkat.

Hal ini perlu menjadi perhatian khusus bagi instansi/lembaga apapun yang berwenang terhadap pemanfaatan dan pengelolaan di kawasan pesisir utara dan timur Pulau Bintan, mengingat pola yang sama dengan yang terjadi di pesisir Garut Selatan terkait alih fungsi lahan pesisir juga terjadi di pesisir utara dan timur Pulau Bintan dimana kondisi di lapangan terlihat jelas segala infrastruktur penunjang kegiatan pariwisata di pesisir utara dan timur Pulau Bintan cenderung membangun ke arah laut di sepanjang kawasan pantai.

\section{KESIMPULAN DAN SARAN}

\section{Kesimpulan}

Kerentanan pesisir di utara dan timur Pulau Bintan sangat dipengaruhi oleh geomorfologi, kemiringan pantai, dan laju perubahan garis pantai. Variabel tersebut memiliki kesamaan dengan penelitian sebelumnya yang telah dilakukan pada tahun 2016 di pesisir timur Pulau Bintan. Perbedaan dengan penelitian sebelumnya adalah pada tingkat kerentanan, terdapat beberapa daerah yang mengalami penurunan tingkat kerentanan dan terdapat beberapa daerah yang mengalami peningkatan status kerentanan. Laju abrasi dan sedimentasi (perubahan garis pantai) diduga menjadi faktor penyebab terjadinya perubahan status kerentanan di beberapa lokasi. Hasil penelitian ini dapat menjadi acuan/ referensi terhadap bentuk pemanfaatan dan pengelolaan di kawasan pesisir utara dan timur Pulau Bintan.

\section{Saran}

Sebuah studi untuk menilai kategori tingkat kerentanan suatu kawasan pesisir merupakan hal yang fundamental untuk dijadikan dasar perumusan rancangan pemanfaatan dan pengelolaan potensi kawasan pesisir dan laut. Begitu banyaknya parameter/variabel yang menjadi indikator penilaian serta modifikasi yang dapat dilakukan terhadap parameter/ variabel indikator tersebut tentunya akan memberikan cukup banyak perspektif dalam menilai kategori tingkat kerentanan pesisir di suatu wilayah. Dari hasil penelitian yang dilakukan dengan penelitian yang dilakukan pada tahun 2016 terdapat perbedaan kategori kerentanan, hal ini tidak terlepas dari jumlah dan variabel yang digunakan. Oleh sebab itu studi yang lebih mendalam mengenai parameter/variabel 
apa saja yang paling tepat untuk menjadi indikator penilaian tingkat kerentanan suatu kawasan pesisir dirasa sangat perlu untuk dilakukan agar tingkat keakuratan penilaian menjadi lebih tinggi lagi.

\section{UCAPAN TERIMA KASIH}

Ucapan terima kasih diberikan kepada Direktorat Jenderal Penguatan Riset dan Pengembangan, Kementerian Riset dan Teknologi/Badan Riset dan Inovasi Nasional yang telah memberikan hibah dana Penelitian Dosen Pemula (PDP). Ucapan terima kasih juga diberikan kepada Fakultas Ilmu Kelautan dan Perikanan, Universitas Maritim Raja Ali Haji yang telah memberikan dukungan terhadap penelitian in. Kami juga berterima kasih kepada reviewer atas komentar dan saran konstruktif yang secara substansial meningkatkan isi artikel ini.

\section{DAFTAR PUSTAKA}

Aedla R, Dwarakish GS, Reddy DV. 2015. Automatic Shoreline Detection and Change Detection Analysis of Netravati-Gurpur Rivermouth Using Histogram Equalization and Adaptive Thresholding Techniques. Aquatic Procedia. 4: 563-570. https://doi. org/10.1016/j.aqpro.2015.02.073.

Angkotasan AM, Nurjaya IW, Natih NMN. 2012. Analisis Perubahan Garis Pantai di Pantai Barat Daya Pulau Ternate, Provinsi Maluku Utara. Jurnal Teknologi Perikanan dan Kelautan. 3(1): 11-22. https://doi. org/10.24319/jtpk.3.11-22.

Bagli S, Soille P, Fermi E. 2004. Automatic Delineation of Shoreline and Lake Boundaries from Landsat Satellite Images. Proceedings of Initial ECOIMAGINE GI and GIS for Integragted Coastal Management.

Bukvic A, Rohat G, Apotsos A, de Sherbinin A. 2020. A Systematic Review of Coastal Vulnerability Mapping. Sustainability (Switzerland). https:// doi.org/10.3390/su12072822.

Chandrasekar N. 2013. Coastal Vulnerability and Shoreline Changes for Southern Tip of India-Remote Sensing and GIS Approach. Journal of Earth Science \& Climatic Change. https://doi. org/10.4172/2157-7617.1000144.

Dhiauddin R, Gemilang WA. 2018.
Coastline Alteration Rate of Weh Island, Aceh Province, Indonesia. IOP Conference Series: Earth and Environmental Science. https://doi.org/10.1088/17551315/216/1/012010.

Dolan AH, Walker IJ. 2006. Understanding Vulnerability of Coastal Communities to Climate Change Related Risks. Journal of Coastal Research. 39: 1316-1323.

Field CB, Barros VR, Dokken DJ, Mach KJ, Mastrandrea MD, Bilir TE, Chatterjee M, Ebi KL, Estrada YO, Genova RC, Girma B, Kissel ES, Levy AN, MacCracken S, Mastrandrea PR, White LL. 2014. Climate Change 2014: Impacts, Adaptation, and Vulnerability. Part A: Global and Sectoral Aspects. IPCC.

Gemilang WA, Husrin S, Wisha UJ, Kusumah G. 2007. Kerentanan Pesisir terhadap Bencana Tanah Longsor di Bungus, Sumatera Barat, dan Sekitarnya Menggunakan Metode Storie. Jurnal Geosaintek. 3(1): 37-44. https://doi. org/10.12962/j25023659.v3i1.2954.

Giambastiani BMS, Colombani N, Greggio N, Antonellini M, Mastrocicco M. 2017. Coastal Aquifer Response to Extreme Storm Events in Emilia-Romagna, Italy. Hydrological Processes. https: / / doi.org/ 10.1002/hyp.11130.

Hammar-Klose ES, Pendleton EA, Thieler ER, Williams SJ, Norton GA. 2003. Coastal Vulnerability Assessment of Cape Cod National Seashore (CACO) to Sea-Level Rise. USGS Open File Report 02-233.

Hamuna B, Sari AN, Alianto A. 2018. Kajian Kerentanan Wilayah Pesisir Ditinjau dari Geomorfologi dan Elevasi Pesisir Kota dan Kabupaten Jayapura, Provinsi Papua. Jurnal Wilayah dan Lingkungan. 6(1): 1-14. https://doi. org/10.14710/jwl.6.1.1-14.

Handartoputra A, Purwanti F, Hendrarto B. 2015. Penilaian Kerentanan Pantai di Sendang Biru, Kabupaten Malang, terhadap Variabel Oceanografi Berdasarkan Metode CVI (Coastal Vulnerability Index). Diponegoro Journal of Maquares. 4(1): 91-97.

Imran Z, Sugiarto SW, Muhammad AN. 2020. Coastal Vulnerability Index Aftermath Tsunami in Palu Bay, Indonesia. IOP Conference Series: Earth and Environmental Science. https://doi.org/10.1088/1755- 
1315/420/1/012014.

Irawan S, Fahmi R, Lubis $\mathrm{MZ}$, Aji $\mathrm{SB}$, Roziqin A, Khoirunnisa H. 2018. Hydro-oceanographic Condition (Tide, Sea Current, and Waves) of Nongsa Batam Sea. Journal of Applied Geospatial Information. https://doi. org/10.30871/jagi.v2i2.968.

Islam MA, Mitra D, Dewan A, Akhter SH. 2016. Coastal Multi-hazard Vulnerability Assessment Along the Ganges Deltaic Coast of Bangladesh-a Geospatial Approach. Ocean and Coastal Management. https: / / doi.org/10.1016/j. ocecoaman.2016.03.012.

Joesidawati MI. 2016. Penilaian Kerentanan Pantai di Wilayah Pesisir Kabupaten Tuban terhadap Ancaman Kerusakan. Jurnal Kelautan: Indonesian Journal of Marine Science and Technology. 9(2): 188-198. https://doi.org/10.21107/ jk.v9i2.1667.

Kalay DE, Lopulissa VF, J YAN. 2018. Analisis Kemiringan Lereng Pantai dan Distribusi Sedimen Pantai Perairan Negeri Waai Kecamatan Salahutu Provinsi Maluku. Jurnal Triton. 14(1): 10-18.

Kasim F, Siregar VP. 2012. Penilaian Kerentanan Pantai Menggunakan Metode Integrasi CVI-MCA Studi Kasus Pantai Indramayu. Forum Geografi. 26(1): 65-76. https://doi. org/10.23917/forgeo.v26i1.5051.

Koroglu A, Ranasinghe R, Jiménez JA, Dastgheib A. 2019. Comparison of Coastal Vulnerability Index Applications for Barcelona Province. Ocean and Coastal Management. https://doi.org/10.1016/j. ocecoaman.2019.05.001.

Kumar AA, Kunte PD. 2012. Coastal Vulnerability Assessment for Chennai, East Coast of India Using Geospatial Techniques. Natural Hazards. https://doi.org/10.1007/ s11069-012-0276-4.

Mahmood R, Ahmed N, Zhang L, Li G. 2020. Coastal Vulnerability Assessment of Meghna Estuary of Bangladesh Using Integrated Geospatial Techniques. International Journal of Disaster Risk Reduction. https://doi. org/10.1016/j.ijdrr.2019.101374.

Marwasta D, Priyono KD. 2016. Analisis Karakteristik Permukiman DesaDesa Pesisir di Kabupaten Kulonprogo. Forum Geografi. 21(1):
57-68. https://doi.org/10.23917/ forgeo.v21i1.1819.

Rajasree BR, Deo MC. 2020. Assessment of Coastal Vulnerability Considering the Future Climate: A Case Study Along The Central West Coast of India. Journal of Waterway, Port, Coastal, and Ocean Engineering. https:// doi.org/10.1061/(ASCE)WW.19435460.0000552 .

Reimann L, Vafeidis AT, Brown S, Hinkel J, Tol RSJ. 2018. Mediterranean UNESCO World Heritage At Risk from Coastal Flooding and Erosion Due to Sea-level Rise. Nature Communications. 9(4161): 1-11. https://doi.org/10.1038/s41467018-06645-9.

Reiners WA, Driese KL. 2001. The Propagation of Ecological Influences Through Heterogeneous Environmental Space. BioScience. 51(11): 939-950. https://doi.org/10.1641/00063568(2001)051[0939:TPOEIT]2.0. $\mathrm{CO} ; 2$.

Rizzo A, Vandelli V, Buhagiar G, Micallef AS, Soldati M. 2020. Coastal Vulnerability Assessment Along The North-eastern Sector of Gozo Island (Malta, Mediterranean Sea). Water (Switzerland). https://doi. org/10.3390/w12051405.

Royo ML, Ranasinghe R, Jiménez JA. 2016. A Rapid, Low-cost Approach to Coastal Vulnerability Assessment at A National Level. Journal of Coastal Research. 32(4): 932945. https://doi.org/10.2112/ JCOASTRES-D-14-00217.1.

Sekovski I, Del Río L, Armaroli C. 2020. Development of A Coastal Vulnerability Index Using Analytical Hierarchy Process and Application to Ravenna Province (Italy). Ocean and Coastal Management. https: / / doi.org/10.1016/j. ocecoaman.2019.104982.

Suhana MP, Nurjaya IW, Natih NMN. 2016. Analisis Kerentanan Pantai Timur Pulau Bintan, Provinsi Kepulauan Riau Menggunakan Digital Shoreline Analysis System dan Metode Coastal Vulnerability Index. Jurnal Teknologi Perikanan dan Kelautan. 7(1): 21-38. https://doi.org/10.24319/jtpk.7.2138.

Suhana MP, Nurjaya IW, Natih NMN. 2018. Patterns and Tidal Characteristics of East Coast of Bintan Island, Riau 
Archipelago Province. Journal of Applied Geospatial Information. 2(1): 98-101. https://doi.org/10.30871/ jagi.v2i1.642.

Suprapto O, Harahap S, Herawati T. 2016. Analisis Kerantanan Fisik Pantai di Pesisir Garut Selatan Jawa Barat. Jurnal Perikanan dan Kelautan Unpad. 2(2): 51-57.

Thieler ER, Hammar-Klose ES. 2000. National Assessment of Coastal Vulnerability to Sea-Level Rise: Preliminary Results for the U.S. Gulf of Mexico Coast. North. https://doi. org/10.3133/ofr00179.

Ward PJ, Marfai MA, Yulianto F, Hizbaron DR, Aerts JCJH. 2011. Coastal Inundation and Damage Exposure Estimation: A Case Study for Jakarta. Natural Hazards. 56(3): 899-916. https://doi.org/10.1007/s 11069 010-9599-1.

Yin J, Yin Z, Wang J, Xu S. 2012. National Assessment of Coastal Vulnerability to Sea-level Rise for the Chinese Coast. Journal of Coastal Conservation. https://doi.org/10.1007/s11852012-0180-9. 